\title{
Challenges facing the early childhood development sector in South Africa
}

\begin{abstract}
In this review article, the context of young children in South Africa in 2012 is described and the main challenges affecting children and the early childhood development sector (ECD) in South Africa are investigated. A situation analysis of ECD in South Africa was undertaken using South African government ECD policy and programme implementation reports. There has been progress since 1994, both quantitatively and qualitatively. The number of children in Grade R has trebled since 2001, government education and social development budgets have increased substantially and $58 \%$ of children at ECD centres nationally are now subsidised. More children are in provision and in better quality provision than before. However, much still remains to be done before we can say with confidence that the needs of our youngest children are being met. This study identifies infrastructure, nutrition, ECD programmes, teacher training, institutional capacity and funding as the major gaps in ECD provision.
\end{abstract}

Keywords: early childhood development (ECD); education; South Africa; Grade R; nonprofit organisations; policy.

Eric Atmore, Department of Social Development, University of Cape Town. E-mail: eric. atmore@uct.ac.za. Lauren-Jayne van Niekerk, Centre for Early Childhood Development, University of Cape Town. E-mail: cecd@iafrica.com. Michaela Ashley-Cooper, Centre for Early Childhood Development. E-mail: cecd@iafrica.com.
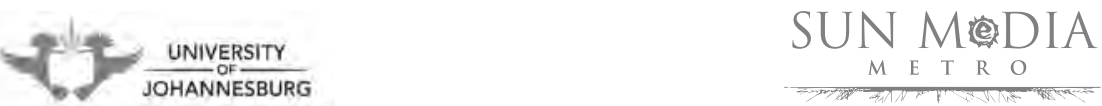


\section{Introduction}

The majority of young children in South Africa are negatively impacted by a range of social and economic inequalities. Apartheid and the resultant socio-economic inequalities have created a childhood of adversity for most black South African children in the country, including inadequate access to health care, education, social services and quality nutrition. This has undermined the development of our children. The South African constitution, through the Bill of Rights, makes provision for children's socioeconomic rights, including the right to basic education and protection from neglect, abuse and exploitation. However, South Africa still has a long way to go to effectively meet the needs of the majority of children.

This paper provides a broad overview of the current state of the early childhood development sector in South Africa. This includes describing the context of children, what has been done in ECD since 1994, and the significant challenges affecting the ECD sector in six key areas, namely infrastructure, nutrition, ECD programming, teacher training, institutional capacity and funding.

\section{Early childhood development}

The National Department of Education defines early childhood development (ECD) as “... the processes by which children from birth to nine years of age grow and thrive physically, mentally, emotionally, morally and socially" (DoE, 2001a). Early childhood development is recognised as the foundation for success in future learning. Quality early learning programmes prepare children for adulthood, providing them with the necessary opportunities for social, cognitive, spiritual, physical and emotional development. These programmes assist in laying the foundation for holistic development, whilst cultivating a love for lifelong learning (Biersteker \& Dawes, 2008).

The National Department of Education is responsible for the five to nine year old age cohort, and the Department of Social Development is focused on the birth to four year old age cohort. The Department of Health covers the birth to nine year old age cohort.

\section{Children in South Africa}

There are approximately 6,5 million South African children under the age of seven. Of these, some 3,8 million children $(59,2 \%)$ live in circumstances of dire poverty (DoSD, DoE \& DoH, 2004).

These children, along with their families, teachers, communities, and the South African government face a range of challenges and obstacles. The most significant of these are poverty, education, health and HIV/Aids. 


\section{Poverty}

More than half of South Africa's children live in severe poverty, which jeopardises the realisation of their rights as contained in the South African Constitution (Du Plessis \& Conley, 2007). Children living in poverty are extremely vulnerable, discriminated against and isolated. Monetary poverty is closely connected to poor health and wellbeing, as well as to limited access to education, nutrition, healthcare services and safe environments. The General Household Survey of 2009 showed that $61 \%$ of children in South Africa lived below the poverty line (with a per capita income below R522 per month). Closely linked to this income poverty indicator is unemployment. Statistics SA (2010) indicated that $36 \%$ of children reside in households where no adults are employed.

The government does provide financial support for children when their parents are too poor to do so, in order for them to meet their basic needs. This is achieved through social assistance programmes, such as the Child Support Grant, paid to the caregivers of eligible children. While this grant has increased over the years since its introduction, from R100 per month in 1998 to R280 in April 2012, this is still far too little. By April 2011, 10.5 million children under the age of 16 years were accessing the Child Support Grant, which makes it the largest child poverty alleviation programme in South Africa. Research has shown that this grant has contributed towards food, education as well as basic goods and services for millions of children across the country (South African Child Gauge, 2010).

\section{Education}

Education is a basic human right and is fundamental to building life-long learning and economic opportunities. South Africa has a high rate of school enrollment with $97 \%$ of 11,4 million school-going age children in Grades $1-12$ at an educational facility. Encouragingly, by $2011,67 \%$ of five-year-olds were enrolled in Grade R, which suggests progress towards the government's revised goal of universal access to Grade $R$ by 2014 (South African Child Gauge, 2010: 99).

The relevant government departments (namely the Department of Social Development, Education, and Health), has identified the need to increase access to $E C D$ programmes, as well as enhance the quality of ECD programmes and services, specifically for children from disadvantaged backgrounds. Funding to both early childhood development centres (birth to four years of age), through the Department of Social Development, and to Grade R (five to six years of age) through the Department of Education (DoBE, DoSD \& UNICEF, 2010) has been increased. According to the Tracking Public Expenditure and Assessing Service Quality in Early Childhood Development in South Africa report -

... spending within provincial Departments of Education on Grade R increased from R377 million in 2003/04 to a budgeted R983 million in 2007/08 and a projected R1 253 million in 2009/10 (DoBE, DoSD \& UNICEF, 2010). 
With regard to children between the ages of o to 4 years attending ECD facilities, in 2006/07 the Department of Social Development spent R350 million by providing 5,531 registered ECD sites with subsidies for a total of 314,912 children (DoBE, DoSD \& UNICEF, 2010).

Although much has been done to improve access and quality of early learning programmes in both ECD facilities and Grade R classrooms, there is a long way to go in the enhancement of service delivery (DoBE, DoSD \& UNICEF, 2010). Some of the prominent challenges and obstacles facing ECD facilities include absence of learning materials and resources, especially within the classroom setting, minimal funding, lack of qualified teachers, inadequate security for children whilst at the ECD facility, as well as poor toilet amenities (DoBE, DoSD \& UNICEF, 2010).

\section{Health}

The United Nations Convention on the Rights of the Child (1989) states that every child has "the right to the enjoyment of the highest attainable standard of health". A commonly used gauge for measuring health status and socio-economic development are infant and child mortality rates. In South Africa, one of the Millennium Development Goals (adopted in 2000) for reducing poverty and inequality in the world, aims to reduce the under-five mortality rate by two-thirds from the 1990 figure of 60 deaths per 1,000 live births to that of 20 by 2015 . ASSA 2008 has estimated that the infant mortality rate has steadily declined from 52 deaths per 1,000 live births in 2000 to 34 in 2010 (as cited in the South African Child Gauge, 2011).

Despite the fact that the Government has established programmes aimed at reducing hunger, malnutrition and food insecurity, child hunger remains a challenge with approximately $16 \%$ of children living in households where child hunger has been reported. This figure indicates a substantial decrease in reported child hunger from $30 \%$ in 2002 and $18 \%$ in 2007 (South African Child Gauge, 2011). Hunger is highest among black African children with $17 \%$ of the total black African child population living in households that reported child hunger compared to $13 \%$ of coloured children, $2 \%$ Indian and only $1 \%$ of white children.

The South African Constitution states that everyone has the right to sufficient water, as well as to an environment that is not harmful to their health or well-being. Water is a requirement for health, hygiene and sanitation. Whilst young children have the right to sufficient water, the water that they have access to is often of poor quality resulting in our young children becoming particularly vulnerable to cholera and diarrhoea. In 2009, seven million children lived in households that did not have direct access to clean drinking water, and there had been very little improvement in children's access to water between 2002 and 2009 (South African Child Gauge, 2010: 102). In addition to this, there is a lack of children's access to basic sanitation in many South African households. A significant number of children do not have access to adequate sanitation facilities, thereby making use of unventilated pit latrines, buckets and/or 
open land. Inadequate sanitation results in young children becoming susceptible to a range of illnesses and diseases that compromise their health and nutritional status.

\section{HIV/Aids}

South Africa is the country with the highest number of people living with HIV. Paediatric HIV is propelled by the adult epidemic with most children being infected prior to, and during the birth process, and later through breastfeeding. The Actuarial Society of South Africa (ASSA) 2008 AIDS and Demographic Model has indicated that while the prevalence of paediatric HIV is on the increase, the rate at which it is spreading is decreasing (as cited in the South African Child Gauge, 2011). This is attributed to the increased survival rates of children who now have access to antiretroviral treatment (ART). In 2010, an estimated 438,000 children under the age of 15 years were HIV positive, with the Western Cape having the lowest HIV-prevalence rate at 1,2\% in 2010, compared to KwaZulu-Natal which had the highest rate of $4,1 \%$.

Many children reside in child-headed households in which all members are under the age of 18 years. Family and community networks support the growing numbers of orphaned children in our country, mainly as a result of the HIV/Aids pandemic. The General Household Survey of 2009 indicated that South Africa is home to 95,000 children living in child-headed households. These children are more at risk than others of poor access to services, inconsistent income and poor living circumstances (South African Child Gauge, 2011).

\section{What has been done in ECD since 1994?}

As a country South Africa has come a long way since the watershed year, 1994. There have been a number of initiatives affecting the lives of young children directly. Some have been very positive and others less successful. These successes include:

1. The signing of the Convention on the Rights of the Child by our government in 1995 .

2. Free medical and health care services for pregnant women and for children aged birth to six years of age.

3. The establishment of a Directorate for Early Childhood Development within the national Education Department.

4. The establishment of a Children's section within the national Social Development Department.

5. An Education White Paper (number 5) on early childhood development and a Welfare White paper with a section on early childhood development.

6. The introduction of Grade $\mathrm{R}$ for children aged five years turning six years.

7. The Expanded Public Works Programme has a focus on early childhood development. 
8. A nationwide ECD Audit surveying 23,482 ECD sites was successfully completed in 2000.

9. The nine provincial Social Development Departments making ECD subsidies available for ECD sites each year.

10. The nine provincial Education Departments making Grade R grants-in-aid available.

11. The Children's Act, with two chapters that deal with partial care facilities and early childhood development programmes, has been passed by Parliament.

12. Many grant-making organisations and companies have continued their support of the early childhood development sector.

13. 10.5 million children received the Child Support Grant (CSG) by April 2011.

\section{ECD policy priority}

The main ECD policy priority of the South African government after 2001 has been the establishment of a national system of provision, called Grade R, for children aged five to six (DoE, 2001a). Over the past 11 years this goal has been partially achieved, although there is still much to be done in order for this policy goal. This section explores the relevant aspects of current Grade R provisioning, including funding and teacher training and qualifications.

Using DBE statistics, enrollment as at the first quarter of 2011 (the latest figures) was 734,654. Table 1 shows the provincial distribution of these children. According to department officials, this figure excludes children in independent and communitybased sites, but no figures are given for these, and these numbers could not be verified.

Based on the Department of Education statistics, 493,129 additional children entered Grade $\mathrm{R}$ in the first 10 years after the release of the education White Paper number 5. The rate of take up of Grade R places has been 37,201 in 2002; 36,661 in 2003; 41,100 in 2004; 48,710 in 2005; 36,444 in 2006; 45,884 in 2007; 56,274 in 2008; 76,424 in 2009; 86,980 in 2010 and 27,451 in 2011.

It is clear that the compulsory/universal provision target was not reached by 2010, as envisaged in the education White Paper 5 , and was extended by the President to 2014. At the present take up rate it will take the country at least until 2018 to reach Government's target of a place in Grade R for every child before Grade 1.

Table 1 excludes any comment on quality. There is, however, certainly considerable unevenness in quality across the nine provinces. 


\begin{tabular}{|c|c|c|c|c|c|c|c|c|c|c|}
\hline : & $\begin{array}{l}\hat{n} \\
\hat{L} \\
\hat{\sigma} \\
\sigma\end{array}$ & $\begin{array}{l}\tilde{\tilde{N}} \\
0 \\
\hat{\sim}\end{array}$ & $\begin{array}{l}\infty \\
0 \\
m \\
\tilde{i}\end{array}$ & $\begin{array}{l}\bar{m} \\
\hat{0} \\
\dot{0}\end{array}$ & $\begin{array}{l}\frac{a}{n} \\
\stackrel{n}{n}\end{array}$ & 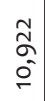 & $\begin{array}{l}m \\
\sigma \\
\bar{m}\end{array}$ & $\begin{array}{l}\frac{N}{\sigma} \\
\hat{m}\end{array}$ & $\begin{array}{l}\stackrel{0}{+} \\
\stackrel{m}{=}\end{array}$ & 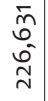 \\
\hline 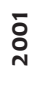 & $\begin{array}{c}m \\
\infty \\
\infty \\
\infty \\
\infty\end{array}$ & $\begin{array}{l}\tilde{O} \\
0 \\
0 \\
0\end{array}$ & $\begin{array}{l}\stackrel{2}{N} \\
\alpha \\
\sim \\
N\end{array}$ & 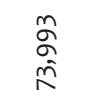 & $\begin{array}{l}m \\
\mathfrak{f} \\
f \\
\infty\end{array}$ & $\begin{array}{l}m \\
0 \\
\infty \\
i n\end{array}$ & $\frac{2}{r}$ & $\begin{array}{l}\mathcal{Y} \\
\dot{f} \\
\dot{f}\end{array}$ & $\underset{\stackrel{M}{f}}{\stackrel{M}{=}}$ & 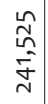 \\
\hline 於 & $\begin{array}{l}\tilde{D} \\
\stackrel{\sim}{n} \\
\tilde{N}\end{array}$ & 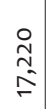 & م) & $\begin{array}{l}\stackrel{N}{m} \\
\stackrel{N}{N}\end{array}$ & $\begin{array}{c}n \\
m \\
\tilde{a} \\
\dot{\sigma} \\
\end{array}$ & $\begin{array}{l}\infty \\
\stackrel{+}{+} \\
\end{array}$ & $\frac{\tilde{f}}{\tilde{m}}$ & 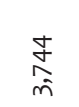 & $\begin{array}{l}\text { No } \\
\text { o. } \\
\text { N }\end{array}$ & $\begin{array}{c}\stackrel{0}{N} \\
\stackrel{2}{0} \\
\stackrel{N}{N}\end{array}$ \\
\hline$\stackrel{m}{\text { m }}$ & $\begin{array}{l}r \\
\hat{m} \\
b^{2} \\
\sigma\end{array}$ & $\begin{array}{l}m \\
\tilde{N} \\
\underline{\sigma} \\
\underline{n}\end{array}$ & $\begin{array}{l}0 \\
\stackrel{0}{0} \\
0 \\
\dot{m}\end{array}$ & 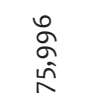 & $\begin{array}{l}2 \\
\stackrel{2}{2} \\
\infty \\
\infty\end{array}$ & $\begin{array}{l}\stackrel{+}{\infty} \\
\infty \\
\tilde{n} \\
\sim\end{array}$ & $\begin{array}{l}\stackrel{n}{N} \\
\stackrel{m}{\sim} \\
\dot{f}\end{array}$ & $\begin{array}{l}\stackrel{8}{0} \\
\text { in } \\
\text { in }\end{array}$ & $\begin{array}{l}\tilde{N} \\
\hat{n} \\
\bar{m}\end{array}$ & $\begin{array}{c}0 \\
m \\
m \\
\hat{n} \\
m\end{array}$ \\
\hline $\begin{array}{l}\text { ষ } \\
\text { ঃ }\end{array}$ & 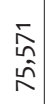 & $\mid \begin{array}{c}0 \\
0 \\
0 \\
0 \\
0 \\
0\end{array}$ & \begin{tabular}{l}
$\circ$ \\
\multirow{\sigma}{0}{} \\
$\dot{f}$
\end{tabular} & $\begin{array}{l}\infty \\
\circ \\
\stackrel{1}{n} \\
\end{array}$ & $\begin{array}{l}\stackrel{\sim}{N} \\
\hat{\sigma} \\
\infty\end{array}$ & 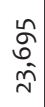 & $\begin{array}{l}\text { n } \\
\tilde{S} \\
\text { in }\end{array}$ & $\begin{array}{l}n \\
\infty \\
\infty \\
\text { in }\end{array}$ & $\begin{array}{l}\stackrel{D}{N} \\
\stackrel{\bar{m}}{二}\end{array}$ & 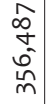 \\
\hline 芒 & $\begin{array}{l}\bar{m} \\
\hat{\sim} \\
\hat{\tilde{O}} \\
\stackrel{0}{0}\end{array}$ & 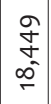 & $\begin{array}{l}m \\
\hat{o} \\
\dot{\sigma}\end{array}$ & $\begin{array}{l}\stackrel{0}{N} \\
\text { న } \\
\text { N }\end{array}$ & 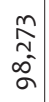 & $\begin{array}{l}\bar{f} \\
\tilde{f}\end{array}$ & $\begin{array}{l}\hat{m} \\
\hat{\sigma} \\
\end{array}$ & \begin{tabular}{l}
$\infty$ \\
\multirow{2}{n}{} \\
$\hat{n}$
\end{tabular} & $\begin{array}{c}\stackrel{0}{\infty} \\
m \\
\hat{N} \\
\tilde{m}\end{array}$ & $\begin{array}{l}\hat{\sigma} \\
\hat{\tilde{n}} \\
\hat{\alpha}\end{array}$ \\
\hline $\begin{array}{l}\text { ๖ } \\
\text { ঃ }\end{array}$ & $\begin{array}{l}0 \\
0 \\
m \\
o \\
\sigma \\
0\end{array}$ & $\mid \begin{array}{l}N \\
0 \\
0 \\
0 \\
N\end{array}$ & 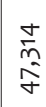 & \begin{tabular}{l}
$\infty$ \\
\multirow{\sigma}{\alpha}{} \\
నু
\end{tabular} & $\begin{array}{l}\stackrel{\sigma}{0} \\
\alpha \\
\hat{i} \\
0\end{array}$ & $\begin{array}{c}\stackrel{+}{m} \\
\stackrel{\sim}{N}\end{array}$ & $\begin{array}{l}\tilde{c} \\
\stackrel{\Sigma}{n}\end{array}$ & 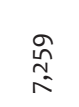 & $\begin{array}{l}\stackrel{0}{\hat{n}} \\
\stackrel{m}{m}\end{array}$ & $\begin{array}{l}\bar{f} \\
\bar{f} \\
\bar{f} \\
\bar{f}\end{array}$ \\
\hline 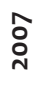 & $\begin{array}{c}\mathfrak{c} \\
\infty \\
\infty \\
\stackrel{I}{\Xi}\end{array}$ & $\mid \begin{array}{l}\mathfrak{y} \\
\mathfrak{y} \\
\mathfrak{z}\end{array}$ & $\begin{array}{l}\bar{m} \\
\sigma \\
\sigma \\
\sigma\end{array}$ & $\begin{array}{l}\text { D } \\
\infty \\
\infty \\
\infty \\
\rightleftharpoons\end{array}$ & $\begin{array}{l}0 \\
m \\
0 \\
\tilde{n} \\
\tilde{n}\end{array}$ & $\begin{array}{l}\hat{\sigma} \\
\alpha \\
\dot{+} \\
m\end{array}$ & $\begin{array}{l}m \\
f \\
\underline{\sigma}\end{array}$ & $\begin{array}{c}\underset{\mathfrak{y}}{\tilde{\infty}} \\
\infty\end{array}$ & $\begin{array}{l}\dot{m} \\
\infty \\
\dot{m} \\
\dot{m}\end{array}$ & $\begin{array}{c}\tilde{N} \\
\tilde{N} \\
\hat{\tilde{N}} \\
\infty \\
+\end{array}$ \\
\hline 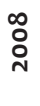 & $\begin{array}{l}\mathfrak{g} \\
\mathfrak{v} \\
m \\
m \\
m\end{array}$ & $\mid \begin{array}{l}2 \\
\delta \\
0 \\
\tilde{n} \\
\tilde{v}\end{array}$ & $\begin{array}{l}2 \\
\sigma \\
\sigma \\
\dot{f}\end{array}$ & 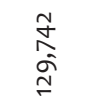 & $\begin{array}{l}m \\
\sigma \\
\sigma \\
o \\
\sigma\end{array}$ & $\begin{array}{l}\bar{\gamma} \\
0 \\
0 \\
\dot{+}\end{array}$ & 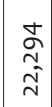 & $\begin{array}{l}\hat{n} \\
\hat{n} \\
\sigma\end{array}$ & $\begin{array}{l}\hat{\hat{v}} \\
0 \\
0 \\
0\end{array}$ & 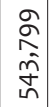 \\
\hline $\begin{array}{l}\text { ㅇ } \\
\text { 유 }\end{array}$ & 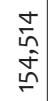 & $\mid \begin{array}{l}\hat{0} \\
\tilde{N} \\
\sim\end{array}$ & $\begin{array}{l}\text { n } \\
\alpha \\
\tilde{f}\end{array}$ & 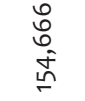 & $\begin{array}{l}\stackrel{2}{\hat{n}} \\
\hat{\sigma} \\
\hat{\sigma}\end{array}$ & \begin{tabular}{l}
\multirow{\sigma}{*}{} \\
$\frac{\sigma}{6}$
\end{tabular} & $\begin{array}{l}\frac{J}{2} \\
\vdots \\
\dot{m}\end{array}$ & $\begin{array}{l}\infty \\
0 \\
\stackrel{0}{1} \\
=\end{array}$ & $\begin{array}{l}\text { Ln } \\
\infty \\
0 \\
0 \\
m\end{array}$ & $\begin{array}{l}m \\
\tilde{N} \\
0 \\
\tilde{N}\end{array}$ \\
\hline$\frac{0}{0}$ & $\begin{array}{l}\tilde{o} \\
\infty \\
\tilde{f} \\
0\end{array}$ & 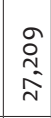 & $\begin{array}{l}0 \\
0 \\
+ \\
0 \\
0 \\
1\end{array}$ & 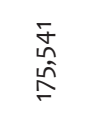 & $\begin{array}{l}\tilde{N} \\
\mathfrak{v} \\
\mathfrak{m} \\
=\end{array}$ & $\begin{array}{l}\infty \\
\stackrel{\infty}{n} \\
\bar{n}\end{array}$ & $\begin{array}{l}0 \\
\text { fo } \\
\text { y }\end{array}$ & 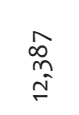 & $\begin{array}{l}m \\
\dot{0} \\
\tilde{r} \\
\tilde{f}\end{array}$ & $\begin{array}{l}m \\
0 \\
N \\
\hat{N} \\
\hat{N}\end{array}$ \\
\hline$\overline{\bar{N}}$ & $\begin{array}{l}\infty \\
\infty \\
\tilde{n} \\
\end{array}$ & 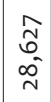 & \begin{tabular}{l}
0 \\
\multirow{2}{*}{} \\
D \\
$\infty$
\end{tabular} & $\begin{array}{l}\stackrel{n}{\infty} \\
\stackrel{n}{n} \\
\stackrel{\infty}{\infty}\end{array}$ & $\begin{array}{l}\mathfrak{g} \\
\mathfrak{1} \\
\stackrel{5}{=} \\
=\end{array}$ & $\begin{array}{l}\stackrel{0}{N} \\
\hat{0} \\
i n\end{array}$ & $\begin{array}{l}\hat{m} \\
\alpha \\
\hat{y} \\
y\end{array}$ & $\frac{m}{\stackrel{n}{n}} \frac{1}{n}$ & $\begin{array}{l}\tilde{\widetilde{N}} \\
\tilde{\delta} \\
\stackrel{0}{n}\end{array}$ & 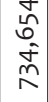 \\
\hline 选 & 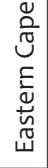 & 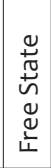 & 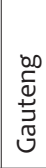 & 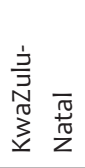 & 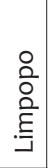 & 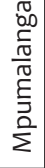 & 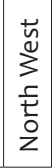 & 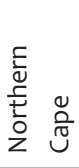 & 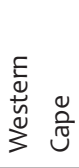 & $\begin{array}{l}\overrightarrow{\leqslant} \\
\vdots \\
\vdash\end{array}$ \\
\hline
\end{tabular}


Based on the Department of Basic Education (DoBE) school realities figures, it is relatively easy to calculate the national provision rate for Grade R. Just over 1,1 million children enter Grade 1 each year; therefore, the provision rate for Grade R currently stands at approximately $67 \%$.

\section{Funding of Grade R}

Education White Paper 5 indicates that financial responsibility for Grade $R$ is the responsibility of provincial education departments and in the short term, provision is made for subsidies to be paid to schools to allow them to establish Grade R facilities. Eventually, Grade R sites will be funded via Norms and Standards for Grade R funding. The intention is to subsidise Grade $\mathrm{R}$ by $75 \%$, because "the financial burden for ECD falls disproportionately on the poor.” (DoE, 2001a: 12).

White Paper 5 also states that the Grade R programme is able to function at -

... a cost considerably lower than primary school-based provision since the latter uses provincially-employed educators, whereas the practitioners at communitybased sites are not employed by government and are paid considerably less (DoE, 2001a: 30).

Actual funding for Grade R from 2004/5 to 2008/9 is presented in Table 2.

Table 2: Grade R expenditure by province, 2004/05 to 2008/09 (R'000).

\begin{tabular}{|l|c|c|c|c|c|}
\hline \multicolumn{1}{|c|}{ Province } & $\mathbf{2 0 0 4 / 5}$ & $\mathbf{2 0 0 5 / 6}$ & $\mathbf{2 0 0 6 / 7}$ & $\mathbf{2 0 0 7 / 8}$ & $\mathbf{2 0 0 8 / 9}$ \\
\hline Eastern Cape & $\mathbf{3 6 , 9 3 7}$ & $\mathbf{3 9 , 8 1 7}$ & $\mathbf{6 9 , 9 4 1}$ & $\mathbf{1 2 0 , 2 1 8}$ & 145,486 \\
\hline Free State & $\mathbf{2 9 , 5 0 9}$ & $\mathbf{3 3 , 5 8 5}$ & $\mathbf{4 9 , 6 3 8}$ & 52,146 & 54,614 \\
\hline Gauteng & 51,807 & 49,000 & 79,000 & 109,000 & 149,000 \\
\hline KwaZulu-Natal & 79,697 & 68,239 & 102,658 & 117,688 & 125,928 \\
\hline Limpopo & 23,535 & 18,883 & 52,723 & 79,976 & 159,033 \\
\hline Mpumalanga & 33,072 & 47,790 & 51,801 & 126,729 & 220,658 \\
\hline Norhern Cape & 13,198 & 15,819 & 18,141 & 30,336 & 42,798 \\
\hline North West & 118,231 & 126,084 & 152,510 & 162,127 & 172,561 \\
\hline Western Cape & 60,135 & 71,923 & 107,397 & 181,930 & 244,923 \\
\hline Total & 446,121 & 471,140 & 683,809 & 980,150 & $1,315,001$ \\
\hline
\end{tabular}

Source: Atmore (2007) extracted from National Budget 2007.

Provincial Grade R spending was at R1,315 billion in 2008/09. Provincial Grade R spending, as a percentage of total education spending, for all provinces was $0,74 \%$ in $2003 / 4$, that is, less than one percent. Expenditure on Grade R by $2008 / 09$ increased to $1,3 \%$ of the total education expenditure. 


\section{Challenges facing the ECD sector}

Notwithstanding the progress made in early childhood development and in Grade $R$ provision since 1994, children in South Africa still face significant challenges. We focus here on infrastructure, nutrition, programme options, ECD teachers, institutional capacity and funding.

\section{Infrastructure}

Infrastructure in ECD is a particular problem in the South African context. Many ECD facilities function without basic infrastructure, such as running water, access to electricity or suitable sanitation. The nation-wide ECD audit of 2000 showed that about $8 \%$ of ECD centres in South Africa have none of these basic infrastructure requirements.

Infrastructure in ECD can be looked at across three distinct facility types; in public schools, in registered community-based ECD facilities, and in unregistered communitybased ECD facilities. In public schools ECD provisioning is limited to Grade R provisioning, whereas registered and unregistered community-based facilities generally provide ECD services to children from birth through to, and including, Grade R.

As such, at public schools the infrastructure for ECD (which is solely Grade R) is part of the school infrastructure which is built and maintained by each province's Department of Education (DoE) or the Department of Public Works. In registered community-based facilities, although the Grade- $\mathrm{R}$ learning programme is registered with the DoBE, the facilities are registered with the Department of Social Development (DoSD), and thus have to meet the requirements of this department. The DoSD does not provide any significant funding for infrastructure upgrades or maintenance (over and above the regular ECD child subsidy), and although it does require an inspection from the local government Environmental Health Office before approving the registration of any ECD community-based facility, any upgrade or maintenance needs to be funded by the Governing Body or owner of the facility. The result is that the infrastructure in registered community-based facilities is of a poorer standard than that of the Grade $\mathrm{R}$ facilities in public schools.

In a study conducted in 2011 by the national Department of Basic Education (DoBE), the Department of Social Development, and UNICEF, researchers found that the infrastructure in the community-based facilities was of a poorer standard than that of the public schools. They also found that the unregistered facilities had a significant amount of buildings that were rated as being "in a bad or very bad condition" (DoBE, DoSD \& UNICEF, 2010: 61). The main reason many of these facilities are unregistered is directly related to the fact that they cannot meet the infrastructure requirements necessary for registration.

More specifically, this study found that: almost all public schools in South Africa had electricity (91\%), whereas almost one third of registered and unregistered community-based ECD facilities did not have any electricity ( $21 \%$ and $27 \%$ respectively). Approximately, half of all facilities, regardless of type, had piped water inside the 
building; between $50 \%$ and $60 \%$ of all ECD facilities had regular flushing toilets, however, roughly $10 \%$ of unregistered community-based ECD facilities made use of buckets or potties, or did not have any toilet facilities whatsoever. A significant portion of ECD facilities had more than 40 children per playroom (the norms which have been set for class ratios are 30 children per class for Grade R and 20 children per class for pre-Grade R). Safety concerns were most prevalent at unregistered ECD facilities: $16 \%$ of these ECD facilities did not have any form of secure fencing around their premises, and roughly $28 \%$ prepared food in the same area in which children spend the majority of their time. In terms of overall infrastructure quality, significant differences were found across the provinces, with the province that the ECD facility was based in being a stronger predictor of infrastructure quality than facility type.

It is important to note that poor infrastructure at ECD facilities not only presents significant health and safety risks to children attending these facilities, but can also point to poor quality ECD service provisioning. The researchers found that, although "programmatically sound ECD" can be provided in poor quality buildings, "an unsafe and impoverished learning environment often is associated with substandard ECD with limited development opportunities" (DoBE, DoSD \& UNICEF, 2010: 94).

The National Department of Basic Education provides physical space for Grade $\mathrm{R}$ classes at public primary schools. The National Department of Social Development, the Department of Public Works and various municipalities have provided buildings for ECD centres, but this is on an ad-hoc basis and is not part of any government programme. It is mostly non-profit organisations (NPOs) and donors who provide funds for infrastructure development and upgrading ECD centres.

\section{Nutrition}

Due to the extraordinarily high prevalence of poverty in South Africa, hunger, malnutrition and food insecurity are significant challenges facing children in communities across the country. Nutrition is a basic physical need. The absence of adequate nutrition greatly affects a child's early development (composed of physical development, brain development, cognitive and learning abilities), which can lead to significant, negative adult outcomes, such as reduced earning potential in adulthood (Wildeman \& Mbebetho, 2005; Victora et al., 2008). The physical effects of inadequate nutrition are severe. Even in mild cases, malnourishment can cause direct and irreversible structural damage to the brain, impair motor development, cause significant developmental retardation, affect cognitive development, impair exploratory behaviour, impair learning abilities and educational achievement, and can have long-lasting impacts on their health (Duggan, Watkins \& Walker, 2008; Victora et al., 2008).

In terms of learning, malnutrition and hunger greatly affect a child's ability to concentrate, focus attention, and perform complex tasks (Wildeman \& Mbebetho, 2005). Children who lack certain nutrients (such as iron and iodine) or those who 
suffer from general malnourishment, or simply hunger, therefore, do not have the same readiness for learning as their healthy, adequately nourished counterparts.

These negative consequences affect children's ability to achieve their full potential, stunting not only the individual child's ability to flourish in adulthood, but collectively limiting the country's potential development (McNeil \& Donald, 2006). Longitudinal research has shown that malnourishment in childhood is directly related to later negative adult outcomes. This can be seen in educational achievement (poor performance in school, and less schooling reached), reduced economic productivity resulting in lower human capital (income and assets), and a higher risk of adult diseases (including chronic diseases such as cancer) (Victora et al., 2008). Consequently, researchers report that the best predictor of human capital in adulthood was heightfor-age at two years, height being directly determined by adequate nutrition (Victora et al., 2008).

The long-lasting effects of inadequate nutrition place significant additional stress on the health care expenditure of a country. Improving nutrition, through various interventions, can bring about not only health and educational benefits to children, but economic benefits to the country as a whole. Interventions in nutrition in South Africa are offered by a number of service providers, including NPOs and private companies. These interventions include school feeding schemes, the provision of deficient micronutrients through fortified sachet powders/pap to homes and community based ECD facilities, the facilitation and start-up of food gardens, as well as skills development and training on nutrition and agricultural development. Government, specifically the Department of Social Development, in the form of an ECD subsidy, and the Department of Education, in the form of the National School Nutrition Programme (NSNP), also contribute to, and run, nutrition programmes.

In the National Audit of ECD Service Quality in South Africa, the Department of Basic Education, Department of Social Development \& UNICEF (2011), found that all ECD facilities surveyed provided some form of nutrition. Not surprisingly, the quality and quantity of the meals varied from public schools (in the form of Grade R classes), to registered community-based ECD facilities and unregistered ECD facilities; with the majority of registered and unregistered community-based ECD facilities offering two or more meals a day, whereas the majority of public schools only offered one meal a day.

In terms of funding for nutrition, the audit found that most public schools (71\%) provided food to the children in their care through the NSNP programme, whereas only $29 \%$ of registered community-based ECD facilities were part of the NSNP programme. At these community ECD facilities, the meals were provided mainly by the facility itself ( $41 \%)$, or the meals were provided by the parents and sent from home (28\%). More than three quarters (79\%) of the unregistered ECD facilities provide meals themselves, and only $37 \%$ indicated that meals were provided by the parents and sent from home. It is important to note that children attending ECD programmes in public schools are most likely to receive their nutrition through the NSNP programme, whereas food for children from registered and subsidised community-based ECD facilities is supposed 
to be funded through the DoSD per child ECD subsidy. However, this subsidy is often also used for administration and personnel costs (HSRC, 2009), and, for this reason, optimal nutritional meal provision is not guaranteed in these ECD centres.

\section{ECD Programming}

The ECD sector offers a number of ECD programme options to meet the needs of children and their caregivers. These programmes include the traditional centre-based ECD model of provision, and 'non-traditional' models, such as playgroups and family outreach programmes. This section sets out these various programme options and provides insight into the best approach to offering various programmes.

Traditional ECD provision involves the common practice of ECD teachers providing ECD care and education for a class of children, ranging from birth to six years of age and is provided in various physical structures. This can take place at public schools (in the form of Grade R classes), and at community-based facilities (in the form of preGrade $\mathrm{R}$ and Grade R classes). Community-based facilities can be further broken down according to physical space; the ECD service can be provided at home-based facilities where an ECD practitioner converts a portion of their house to accommodate children, or it can be provided at centre-based facilities where an ECD teacher or a community has a dedicated building for the children.

Historically, centre-based ECD has been the main form of ECD provision, however, one of the biggest challenges in ECD South Africa today, remains the need to increase access to these programmes. Due to poverty and distance, many families do not have the resources to pay for ECD services and parents, and caregivers cannot afford to send their children to traditional ECD facilities. How to provide access to ECD centres for these children has now become the major challenge. Complementary ECD programme options have been developed to provide services to marginalised young children. Increasingly, it is being accepted that ECD can be provided in various forms and places.

Non-traditional ECD provision involves a range of programme options, usually provided by members of the community, who have been trained by service providers such as ECD NPOs and/or government departments. This form of ECD provision includes two predominant programmes, namely family outreach and play groups.

Family outreach programmes involve the provision of ECD services within a home. Family outreach workers (also referred to as Family or Community Motivators) work with a number of families in a community and visit each family for a set amount of time each week or month, depending on the nature of the specific programme. During a home visit, the family outreach worker works directly with the caregiver by sharing knowledge on how to provide early learning stimulation and on various other important topics such health, safety and nutrition. The family outreach worker also works directly with the children in their homes; demonstrating to the caregiver the various activities that can be done at home, and providing the children with a foundation for their early learning. These programmes aim to empower parents and 
primary caregivers to provide early learning opportunities to their own children. The intention of the family outreach programme is that parents continue to provide these early learning activities and opportunities to their children after the completion of the programme.

Similarly, informal play groups involve the provision of ECD services within a community setting or informal gathering. In these programmes, a fieldworker works with a group of parents and children on early learning activities on a session basis in a local park, in a residential home or at a community hall. The activities focus mainly on the education activities that the parents can do in the home with their children. Playgroups, allow for information sharing between the primary caregivers and parents, and provide a space for supporting them, as well as allowing the parents/ caregivers to support each other. These programmes also allow for groups of children, who usually do not interact with many other children, to interact in large groups, on shared activities.

With these programme options in mind, it is important to note that the best way to provide ECD to children, and, in the process to give them the best possible start in life, is by exposing them to an integrated approach to ECD, where comprehensive services and programmes are provided to ensure holistic development of all children. This integrated approach, with coordination between government departments, ECD NPOs, private sector companies, communities, and caregivers, provides optimal results for young children (DoE, DoSD, DoH \& UNICEF, 2005).

\section{ECD teacher training}

Quality teaching and learning is essential for effective early development to take place. Regardless of the situation or the facility in which a child is placed, a quality teacher can provide a learning environment in which a child can develop optimally and in a holistic manner. To produce quality ECD teachers, various training and education opportunities are made available through full ECD qualifications, as well as through short skills programmes. This section explores the ECD qualifications available in South Africa, and describes how these qualifications affect teaching in various ECD facilities.

In South Africa, qualifications are established on the National Qualifications Framework (NQF) by the South African Qualification Authority (SAQA). Training in these ECD qualifications is offered mainly at Further Education and Training (FET) colleges and ECD non-profit organisations (NPOs). To provide a qualification, the service provider/institution must be accredited by the ETDP-SETA (Education, Training and Development Practices Sector Education and Training Authority).

The Department of Social Development (DoSD) and UNICEF have set out the minimum standards for ECD teacher requirements in the document entitled Guidelines for Early Childhood Development Services (2006). These guidelines state that the minimum qualification for any ECD practitioner is the NQF Basic Certificate: ECD (Level 1) (DoSD \& UNICEF, 2006). 
The original purpose of the Basic Certificate: ECD (Level 1) qualification was to provide access to training to teachers who work in an ECD setting (home-based or centre-based) who, previously, may have been excluded from such training opportunities. It aimed to provide teachers with the necessary skills to meet the basic needs of young children in all areas of their development (physical, mental, emotional, and social). However, this qualification has expired (the last enrollment date was 10/01/2010) and is no longer being offered.

The Further Education and Training Certificate: ECD (Level 4) qualification has become the entry-level qualification for ECD practitioners. This qualification provides ECD practitioners with the necessary skills to facilitate the holistic development of young children (including those children with special needs), and offer quality ECD services in a variety of settings (such as at ECD centres, home-based ECD centres, or within community-based services).

The Higher Certificate and National Diploma: ECD (Level 5) qualifications are intended to provide higher education to experienced ECD teachers.

The question of whether or not training in various qualifications actually produces outcomes of quality teaching as required by the DoSD is not clear. While teacher qualification level is often used as a quality indicator for ECD services, higher levels of qualification do not always predict higher levels of quality teaching. This has been found both in South Africa (e.g. Dlamini et al., 1996; DoE, 2001b), and internationally (e.g. Cassidy et al., 2005).

In a recent study assessing the quality of ECD services in the Western Cape, researchers found that qualification level was not always associated with higher quality outcomes, such as quality of care and learning (HSRC, 2009). They also found that only $35 \%$ of practitioners responsible for infant and toddler classes had any form of ECD qualification, and only $47 \%$ of practitioners responsible for older children had any form of ECD qualification (HSRC, 2009).

There are a number of possible reasons as to why training does not necessarily guarantee quality care and teaching. These could include: a lack of practical demonstration and instruction during training, a lack of on-site support to assist with implementation of theoretical training, and a lack of follow-up support after the completion of training so as to ensure consistent implementation.

In another recent study, conducted in 2011, the researchers found that, throughout South Africa, ECD teachers based in Grade R classes in public schools and those based in community-based facilities are "relatively experienced, and have a fair level of ECD qualification." (DoBE, DoSD \& UNICEF, 2010). They also found that ECD qualification level achieved has a strong association with salary earned. Short courses in ECD and the Basic Certificate: ECD (Level 1) carries minimal financial gains, but ECD certificates at Levels 4 and 5 carry far greater financial gains, with tertiary education in ECD carrying the most financial gain for the teacher.

Table 3 lists ECD qualification figures, by NQF level for April 2005 - July 2006. 
Table 3: Qualifications statistics by NQF level (April 2005 - July 2006).

\begin{tabular}{|l|c|}
\hline \multicolumn{1}{|c|}{ Qualification title } & Number qualified \\
\hline Basic Certificate: ECD (Level 1) & 71 \\
\hline National Certificate: ECD (Level 4) & 5,375 \\
\hline Higher Certificate: ECD (Level 5) & 161 \\
\hline National Diploma: ECD (Level 5) & 27 \\
\hline Total & 5,634 \\
\hline
\end{tabular}

* Source: The Uptake and Impact of Qualifications and Unit Standards in the Subfield: Early Childhood Development, Directorate Strategic Support: SAQA, Pretoria (2007).

The NQF provides a qualification framework for ECD teachers which was previously absent. Moreover, it provides a number of qualifications which all facilitate the improvement of teaching at the Grade R and ECD levels. Finally, the NQF establishes career-pathing opportunities for ECD teachers.

\section{Institutional Capacity}

According to the Guidelines for Early Childhood Development Services (DoSD \& UNICEF, 2006), it is crucial that administrative and management systems are developed and put in place for the effective running of an ECD centre. In order for ECD facilities to adhere to the minimum standards, set by the Department of Social Development, specific processes and structures are required to be in place.

The Tracking Public Expenditure and Assessing Service Quality in Early Childhood Development in South Africa study, (DoBE, DoSD \& UNICEF, 2010), showed that community-based ECD facilities in South Africa appear to be less advanced in terms of financial management and governance than that of ECD facilities in the public school system.

The financial management of many of the registered community-based ECD facilities is poor; more than $50 \%$ of these sites do not have many of the necessary administrative documents and structures in place, including such items as a petty cash book. The study found that only $70 \%$ of community-based ECD facilities had annual financial statements, and of those who were recipients of the DoSD subsidy, only $77 \%$ could indicate how much they had received in 2008 . Furthermore, only $61 \%$ of the facilities who charge centre fees were able to supply evidence on income from fees, and only $36 \%$ of all ECD facilities surveyed kept salary disbursement records. Approximately $95 \%$ of community-based ECD facilities had a bank account and in very few instances were these bank accounts in the name of the owner or another person involved in the running of the facility (DoBE, DoSD \& UNICEF, 2010).

With regards to the governing bodies in community-based ECD facilities, in the majority of cases, a governing body exists and functions well (three percent of facilities do not have a governing body at all) (DoBE, DoSD \& UNICEF, 2010). 
Encouragingly, the research has shown that the administrative structures within the community-based ECD facilities are fairly good. For example, approximately $90 \%$ of community-based schools have correctly completed attendance registers for children indicating that they are in line with this aspect of the minimum standards set by the Department of Social Development.

With regard to ECD facilities within the public school sector, the institutional capacities of public schools appears to be more sophisticated than that within community-based ECD centres and have more structured governance and financial reporting systems. This could be due to the fact that these ECD facilities form part of public schools and that they have close ties with the Department of Education's administration. With their superior institutional capacity, Grade R facilities in public schools are seen as the benchmark for community-based ECD facilities. Evidence indicates that within public schools, the school governing bodies are well established and have effective methods of accountability to parents.

\section{Funding}

The vast portion of ECD centre funding nation-wide is from parents' fees. Government funding for ECD comes mainly from the Department of Social Development and the Department of Education at provincial level. There are two primary ways in which the Department of Social Development in each province provides funding to ECD. The first channel of funding is through a subsidy for registered ECD facilities, calculated at R12 per child per day (but varying by province) for those children from birth to four years of age. Some provinces have increased this to R15 per child per day. Only those children whose parent or caregiver's income falls under a specific level, as assessed by an income means test, qualify for the subsidy. This means that only those ECD facilities that cater to the poorest of families benefit from this subsidy (Giese, Budlender, Berry, Motlatla \& Zide, 2011).

The funding and expenditure of various governmental departments and programmes shows that funding for ECD facilities through the subsidy has increased over the last decade from R335 million in 2003/2004 to more than R1 billion in 2011/2012 (Giese, Budlender, Berry, Motlatla \& Zide, 2011). While this increase is encouraging, there are significant disparities across the provinces in terms numbers of centres accessing the subsidy, as well as the actual amount they receive, with many ECD centres not receiving the subsidy at all. This could be due to number of factors, including differences in how provinces calculate the subsidy, and a backlog in the registration process.

The second way in which DoSD provides funding for ECD is through programme funding for NPOs for various ECD programmes. These programmes are usually noncentre based models of ECD provisioning, such as family outreach programmes. Funding for non-centre based programmes for NPOs is significantly smaller than funding for centre-based facilities. 
There are significant differences in this funding across provinces, although each province is greatly underfunded. NPO programmes that receive funding from DoSD include toy libraries, home visiting programmes and informal playgroups. This funding is often once-off funds for pilot projects. The allocation of funding to centre-based ECD programmes points to a general favouring of this form of ECD provisioning, even though non-centre based programmes have the potential to reach the most vulnerable children not currently being reached.

The Department of Education provides funding to Grade R programmes. The three primary channels of funding are: funding for Grade R in public schools; subsidies for registered community-based Grade $R$ facilities (either in the form of a per child subsidy or as the payment of salaries for Grade R teachers); and funding for training fees and stipends for those ECD practitioners who receive learnerships.

Researchers have found that the share of ECD budget in the total education budget allocated to the DoE has increased from 0,7\% in 2006/2007 to 2\% in 2012/2013 (Giese, Budlender, Berry, Motlatla \& Zide, 2011). Once again, while this increase is encouraging, there are also significant variations in Grade $\mathrm{R}$ funding across the provinces, with most of the funding going towards Grade R facilities in public schools.

In the Audit of ECD service quality in South Africa, the Department of Basic Education, Department of Social Development \& UNICEF (2011) found that more than half of registered community-based ECD facilities receive funding from DoSD $(37,7 \%$ receive solely from DoSD, and $19,5 \%$ receive from DoSD and DoE), and that almost $40 \%$ of facilities receive funding from DoE (20,1\% receive funding solely from DoE). In their sample, approximately one quarter of registered community-based facilities (22,6\%) receive no funding from either department.

Table 4 illustrates the allocations for early childhood development programmes (including Grade R) in the 2010 budget. The programme accounts for a small share of the overall provincial education budgets.

Table 4: Provincial Budgets for Early Childhood Education Programme (R1 000).

\begin{tabular}{|l|c|c|c|}
\hline \multicolumn{1}{|c|}{ Province } & $\mathbf{2 0 1 0 / 1 1}$ & $\mathbf{2 0 1 1 / 1 2}$ & $\mathbf{2 0 1 2 / 1 3}$ \\
\hline Eastern Cape & 528,492 & 652,168 & 676,000 \\
\hline Free State & 95,738 & 100,978 & 105,717 \\
\hline Gauteng & 55,7541 & 660,215 & 679,843 \\
\hline KwaZulu-Natal & 598,678 & 722,054 & 758,157 \\
\hline Limpopo & 237,432 & 249,253 & 267,750 \\
\hline Mpumalanga & 124,553 & 155,718 & 134,667 \\
\hline Northern Cape & 47,930 & 51,655 & 55,673 \\
\hline North West & 209,020 & 224,109 & 239,553 \\
\hline Western Cape & 342,657 & 363,593 & 384,764 \\
\hline TOTAL & $2,742,032$ & $3,179,743$ & $3,302,124$ \\
\hline
\end{tabular}

* Source: Adapted from Government Funding for Early Childhood Development: Can those who need it get it? (Giese, Budlender, Berry, Motlatla \& Zide, 2001). 


\section{Conclusion}

There has no doubt been an improvement in Grade $R$ and ECD provision over the past 18 years since 1994. The number of children in Grade R has trebled and quality has improved. Government expenditure on Grade $\mathrm{R}$ has increased three-fold since 2008/09. The number of ECD centres registered with the national Department of Social Development has increased to 19,500 and there are currently approximately 836,000 children in a registered ECD centre, of which 488,000 (58\%) received the ECD subsidy. Many more children are in unregistered ECD centres and no recent survey of ECD provision has been done. However, it is fair to say that much work is still needed, if we want to improve the quality of children's lives in South Africa.

\section{References}

Atmore E. (2007) Update on Early Childhood Development in South African and Implication for non-profit organisations. Paper presented at Ntataise Conference, Vanderbijlpark, 20 August 2007.

Biersteker, L. \& Dawes, A. (2008) Early childhood development. In: A. Kraak \& K. Press (eds.), Human resources development review 2008: education, employment and skills in South Africa. Cape Town: HSRC Press.

Cassidy, D. J., Hestenes, L., Hegde, A., Hestenes, S. \& Mims, S. (2005) Measurement of quality in preschool child care classrooms: An exploratory and confirmatory factor analysis of the early childhood environment rating scale-revised. Early Childhood Research Quarterly, 20(3): 345-360.

Department of Basic Education (DBE), Department of Social Development, \& UNICEF. (2010). Tracking Public Expenditure and Assessing Service Quality in Early Childhood Development in South Africa. South Africa.

Department of Education (DoE). (2009). The National School Nutrition Programme; Annual Report 2009/2010. Pretoria: Department of Education.

Department of Education (DoE). (2006). School Realities 2006. Republic of South Africa: DoE.

Department of Education (DoE). (2001a). Education White Paper 5: Meeting the Challenge of Early Childhood Development in South Africa. Pretoria: Department of Education.

Department of Education (DoE). (2001b). The Nationwide Audit of ECD Provisioning in South Africa. Department of Education, Pretoria, South Africa.

Department of Education (DoE), Department of Social Development, Department of Health \& United Nations Children's Fund (UNICEF). (2005). National Integrated Plan for Early Childhood Development in South Africa: 2005-2010 (Draft Document). Pretoria: Government of South Africa. 
Department of Social Development, Department of Education (DoE) \& Department of Health. (2004). Expanded Public Works Programme Social Sector Plan 2004/5 - 2008/9. Version 7 (16.03.2004). Prepared by the Departments of Social Development, Education and Health. Pretoria: South Africa.

Department of Social Development \& United Nations Children's Fund (UNICEF). (2006). Guidelines for Early Childhood Development Services. South Africa.

Dlamini, T., Ebrahim, R., Ntshingila-Khosa, R. \& Soobrayan, B. (1996). An Assessment of NGO Educare Training- Improving Education Quality Project (IEQ) South Africa. Prepared for USAID: Pretoria, South Africa.

Duggan, C., Watkins, J. B. \& Walker, W. A. (2008). Nutrition in Paediatrics: Basic Science, Clinical Application. Hamilton: BC Decker; pp. 127-141.

Du Plessis, P. \& Conley, L. (2007). Children and poverty in South Africa: The right to social security. Educational Research and Review, 2(4): 49-59.

Giese, S., Budlender, D., Berry, L., Motlatla, S. \& Zide, H. (2011). Government funding for early childhood development: Can those who need it get it? South Africa: Ilifa Labantwana.

Human Sciences Research Council. (2009). Western Cape Department of Social Development 2009 Audit of Early Childhood Development Facility Quality. South Africa: Human Sciences Research Council.

Jamieson, L., Bray, R., Viviers, A., Lake, L., Pendlebury, S. \& Smith, C. (Eds.). (2011). South African Child Gauge 2010/2011. Cape Town: Children's Institute, University of Cape Town.

Kibbel, M., Lake, L., Pendlebury, S. \& Smith, C. (Eds.). (2010). South African Child Gauge 2009/2010. Cape Town: Children's Institute, University of Cape Town.

McNeil, J. \& Donald, G. (2006). In raising the world's IQ the secret is in salt. New York Times. [Online.] Available from: http://www.nytimes.com/2006/12/16/health/ 16iodine.html?fta=y. (Accessed ?.)

Office of the High Comissioner of Human Rights. (1989). Convention on the Rights of the Child, UN General Assembly Resolution 44-25. Geneva: United Nations.

Proudlock, P., Dutschke, M., Jamieson, L., Monson, J. \& Smith, C. (Eds.). (2008) South African Child Gauge 2007/08. Cape Town: Children's Institute, University of Cape Town.

South African Qualification Authority (SAQA). (2007). The Uptake and Impact of Qualifications and Unit Standards in the Subfield: Early Childhood Development, Pretoria: SAQA.

Statistics South Africa. (2006). General Household Survey 2006. In: P. Proudlock (ed.), South African Child Gauge 2007/08. Cape Town: The Children's Institute, The University of Cape Town.

Statistics South Africa. (2007). Community Survey, 2007. (Rev. ed.). Pretoria: StatsSA.

Statistics South Africa. (2010). General Household Survey 2009. Pretoria: StatsSA. 
United Nations Children's Fund (UNICEF). (2009). The State of the World's Children: Special Edition. New York: Brodock Press.

Victora, S. G., Adair, L., Fall, C., Hallal, P. C., Martorell, R., Richter, L. \& Sachdev, H. S. (2008). Maternal and child undernutrition 2: Consequences for adult health and human capital. Lancet 371(9609): 340-357.

Wildeman, R. \& Mbebetho, N. (2005). Reviewing ten years of the school nutrition programme. Cape Town: An occasional paper for the Budget Information Service of Idasa. 